\title{
Optimal Surface Preparation for Wood Anatomy Research of Invasive Species by Scanning Electron Microscopy
}

\section{Optimalna priprema površine drva za istraživanje anatomije invazivnih vrsta drva pretražnim elektronskim mikroskopom}

\author{
Original scientific paper • Izvorni znanstveni rad \\ Received-prispjelo: 20. 10. 2019. \\ Accepted-prihvaćeno: 28. 4. 2020. \\ UDK: $630 * 811$ \\ https://doi.org/10.5552/drvind.2020.1958 \\ (C) 2020 by the author(s). \\ Licensee Faculty of Forestry, University of Zagreb. \\ This article is an open access article distributed \\ under the terms and conditions of the \\ Creative Commons Attribution (CC BY 4.0) license.
}

\begin{abstract}
Research was done to develop the optimal method of wood surface preparation for scanning electron microscopy (SEM). Since 2018, environmental scanning electron microscope (ESEMTM) FEI Quanta 250 has been installed at the Department of Wood Science and Technology in Ljubljana. We tested several methods for the pre-preparation and cutting of wood surfaces for SEM analyses. The samples had been either dried, soaked in water and frozen, impregnated with paraffin or simply moistened before cutting. We analysed wood surfaces obtained by splitting, sawing, planing, sanding and cutting on a sliding microtome with different blades. The effect of gold coating on the SEM image quality was also evaluated. Best results were obtained by cutting a pre-moistened surface on a sliding microtome with a low profile replaceable blade and gold coated afterwards. Determined methodology is technically less demanding, not time consuming and obtains results that satisfy needs for wood anatomy research at magnifications up to 12.000x. Guidelines for the optimal preparation of samples were prepared, and theoretical and practical basis for investigations of wood anatomy using SEM were provided. The method was afterwards used in analyses of invasive alien plant species - investigating their anatomical structure in the framework of the AlienPLAntSpEcies - APPLAUSE project (Urban Innovative Actions initiative). It was demonstrated that the use of the SEM opened new scope in detailed investigations of the wood structure and properties.
\end{abstract}

Keywords: wood anatomy; wood surface; scanning electron microscopy; SEM; invasive species; sample preparation

SAŽETAK • Istraživanje je provedeno kako bi se razvila optimalna metoda pripreme drvne površine za pretražnu elektronsku mikroskopiju (SEM). Od 2018. na Odsjeku za znanost i tehnologiju o drvu u Ljubljani instaliran je uređaj za pretražnu elektronsku mikroskopiju u uvjetima okoliša (ESEM $\left.{ }^{T M}\right)$ FEI Quanta 250. Proučavali smo nekoliko metoda za pripremu i rezanje površine drva za SEM analizu. Uzorci su sušeni, potapani u vodi $i$ smrzavani

\footnotetext{
${ }^{1}$ Authors are associate professor, researcher and young researcher at University of Ljubljana, Biotechnical Faculty, Department of Wood Science and Technology, Ljubljana, Slovenia.

${ }^{2}$ Author is head of development at Sivaprodukt d.o.o., Ljubljana, Slovenia.
} 
te prije rezanja impregnirani parafinom ili samo navlaženi. Analizirali smo površine drva dobivene cijepanjem, piljenjem, blanjanjem, brušenjem i rezanjem na mikrotomu različitim oštricama. Također je proučavan utjecaj zlatnog premaza na kvalitetu SEM fotografija. Najbolji rezultati dobiveni su rezanjem prethodno navlažene površine na mikrotomu, i to zamjenjivim noževima niskog profila, nakon čega je površina drva pozlaćena. Primijenjena je metodologija tehnički manje zahtjevna, ne oduzima mnogo vremena, a dobiveni rezultati zadovoljavaju potrebe istraživanja anatomije drva pri povećanju i do 12000 puta. Sastavljene su smjernice za optimalnu pripremu uzoraka te je postavljena teorijska i praktična osnova za istraživanje anatomije drva primjenom SEM-a. Metoda je potom primijenjena za istraživanje invazivnih biljnih vrsta - za ispitivanje njihove anatomske strukture u sklopu projekta AlienPLAntSpEcies - APPLAUSE (Urban Innovative Actions). Potvrđeno je da je upotreba SEM-a otvorila novo područje u detaljnim istraživanjima strukture i svojstava drva.

Ključne riječi: anatomija drva; površina drva; pretražna elektronska mikroskopija; SEM; invazivne vrste; priprema uzorka

\section{INTRODUCTION} 1. UVOD

Wood is a unique natural composite made of several different cells and biopolymers that characterize its properties. Wood anatomy research is obligatory if we aim to characterize wood properties and if we want to understand wood as a raw material for various products. All relevant physical, mechanical as well as aesthetic properties of wood are reflected in its heterogeneous biological cell structure. Most commonly used method for wood anatomy investigation is bright field light microscopy (LM). For this purpose, wood needs to be cut into thin slices, stained and embedded in resin for producing permanent anatomical slides (Prislan et al., 2009). Anatomical structure of wood can also be revealed by several other methods that enable more or less detailed anatomical investigations. Some of research techniques also display wood structure based on detection of some other components; water in wood (in the cell wall and/or lumina) is a component that enables research by Nuclear Magnetic Resonance Imaging - MRI method. Latest devices enable MRI microscopy with spatial resolution up to $50 \mu \mathrm{m}$ and also 3D imaging of wood structure (Merela et al., 2005; 2009a; Oven et al., 2008, 2011; Žlahtič et al., 2017). Wood consists of several different chemical elements and is, therefore, appropriate for Proton Induced X ray Emission (PIXE and micro-PIXE) (Merela et al., 2009b), where surface element distribution can also reveal wood tissue structure. Heterogeneous structure of wood is reflected in different density and this fact is exploited by the Computer Tomography that is commonly used for log scanning (detecting of internal growth anomalies, knots, rots, etc.) as well as for high resolution imaging as Micro CT (Wagner et al., 1989; Bucur, 2003; Mayo et al., 2010; Craig, 2013).

Variation of thermal conductivity inside wood tissue enables Infrared Thermal imaging. Visualization of the thermal variations of a large area of the stem in real time is well suited for spatial analysis of sap movement (Anfodillo et al., 1993; Niemz et al., 1997; Busse, 2001; Chen et al., 2005). Dielectric properties of wood are used in Microwave techniques imaging (Baradit et al., 2005; Hansson et al., 2005; Pastorino et al., 2007; Salvade et al., 2008; Boero et al., 2018), where we can distinguish areas of different density as well as differ- ent moisture content; this method is useful to detect growth defects like knots, etc.

Among all the developed methods, the Scanning Electron Microscopy (SEM) seems to be one of the most powerful techniques that enable very detailed and high magnification wood structure research. SEM uses a high energy electron beam (accelerated electrons) to produce a topographic image by scanning the surface of a sample. The electron beam, emitted by the electron source (electron gun) and collected by electromagnetic lenses in a vacuum chamber, interacts with the atoms of sample surface, providing information about the sample's surface topography, tissue orientation, chemical composition, and many other material properties (Zhou et al., 2006; Goldstein et al., 2017).

The application of SEM in wood science began long before the system became commercially available in 1965, since the wood surface and structure are well suited for this technique (Collett, 2007). The results of the first application in the ground wood pulp fiber were published by Atack and Smith (1956). After that, the potential of SEM began to be exploited in wood anatomy and investigation of wood decay observing small cubes of wood cut through the three planes (Resch and Blaschke, 1968; Findlay et al., 1969). In 1969, a Finnish publication (Ilvessalo-Pfäffli, 1969) demonstrated the wideranging surface topography capabilities of SEM showing micrographs of paper, crystals, as well as some excellent pictures of wood structure. Finally, a comprehensive atlas of three-dimensional structure of wood was presented by Meylan and Butterfield (1978a).

Despite development of techniques with other advantages, SEM remains among the most effective tools for understanding ultrastructural and developmental aspects of secondary xylem and for investigating topography and distribution of exposed features.

However, successful preparation of wooden specimens for SEM without damaging or modifying the wood surface and structure has proven rather challenging. Different protocols have been developed for wood sample preparation for SEM, which often require complex, technically demanding and time-consuming procedures (Exley et al., 1977; Meylan and Butterfield 1978a). Conventional protocols described in literature suggest (before cutting the wood) to soften it in a boiling mixture of glycerine and water until the wood becomes saturated and sinks in the liquid (Jansen et al., 
1998; Collet, 2007). Treatment with hydro fluoric acid or ethylene-diamine (Carlquist, 1982) is also suggested for very hard wood species and subsequent washing for at least $12 \mathrm{~h}$ before sectioning (Sanderson, 1994). Often bleaching with sodium hypochlorite or house hold bleach (15\%) (60-90 min until the surface has lost color) is recommended to remove any protoplasmic debris or vessel contents from the pit chambers (Meylan and Butterfield, 1978b; Nagai et al., 1994; Jansen et al., 2000). After the sample is cut with a microtome, most common procedures consist of sample dehydration with mixture of ethanol and distilled water series (50-70-96 \%) (Jansen et al., 1998) or with series of Methanol-Acetone-N-pentane, each series lasting for 12 hours (Thomas and Nicholas, 1966; Thomas, 2007). In the last step, different drying methods are reported including oven heating at $100{ }^{\circ} \mathrm{C}$ for 3 days and immersion of the wood samples in liquid nitrogen and freeze-drying (Jansen et al., 2008).

Clearly, the above-mentioned SEM protocols have some disadvantages. Besides being expensive and time consuming (duration of sample preparation at least few days), they are subject to a relatively high risk for deflecting structural changes due to chemicals and dehydration process (Hanks and Fairbrothers, 1970; Jansen et al., 2008).

This study aimed to develop a SEM protocol that would enable high performance analyses on a daily basis, achieving high resolution at magnifications up to $8.000 \mathrm{x}$ of the observed wooden traits with minimum sampling preparation. One of the aims was to check how different woodworking processes affect the final appearance of the wood surface. We analyzed wood surfaces obtained by splitting, sawing, planing and sanding. The main purpose of this research was to develop an optimal (technically not too demanding, inexpensive and not time-consuming) wood surface sample preparation for SEM analyses. Our samples for wood anatomical investigations were pre-treated in different ways and cut on a sliding microtome with two different blade types.

The developed method and protocol were afterwards used in analysis of 17 invasive alien plant species - detailed investigation of anatomical structure in the framework of the Applause project (Applause, 2019). Due to the huge amount of obtained data, in this paper we only present a selection of results referring to the following species: black locust (Robinia pseudoacacia), staghorn sumac (Rhus typhina), desert false indigo (Amorpha fruticosa) and red osier dogwood (Cornus sericea).

Black locust (Robinia pseudoacacia) is medium sized, suckering, deciduous tree that typically grows $12-18 \mathrm{~m}$ tall. The popularity of $R$. pseudoacacia as an ornamental, forestry, shelter and land reclamation species has ensured its wide introduction across many regions (Orwa et al., 2019). Native to the Allegheny Mountains, it nowadays covers much of the United States and southern Canada plus parts of Europe, Asia and South America.

The staghorn sumac (Rhus typhina) is a deciduous shrub or small tree growing up to $5 \mathrm{~m}$. It originates from south-eastern Canada and United States, but is widely cultivated as an ornamental tree all over the world (Kossah et al., 2011) becoming one of the most critical invasive alien plant species.

Desert false indigo (Amorpha fruticosa) grows as a thornless shrub up to $6 \mathrm{~m}$ height. It is native in most of the United States, south-eastern Canada and northern Mexico. Because of its nice purple flowers with yellow anthers, it is cultivated as an ornamental plant so the species is present in Europe, Asia, and other continents (Wang et al., 1999).

Red osier dogwood (Cornus sericea) is native throughout northern and western North America from Alaska east to Newfoundland, south to Durango and Nuevo León in the west, and Illinois and Virginia in the east (Ashworth et al., 1993). It is frequently used for waterway bank erosion protection and restoration so it often spreads uncontrolled and becomes invasive.

\section{MATERIALS AND METHODS}

2. MATERIJALI I METODE

\subsection{Material selection and sample preparation} 2.1. Odabir materijala i priprema uzoraka

To test all available surface preparations, we selected beech (Fagus sylvatica) as a reference wood species (e.g., Novak, 2018). To split the wood in radial and tangential plane, we used a sharp chisel, using a woodworking circular saw (saw blade diameter 400 $\mathrm{mm}, 96 \mathrm{ABT}$ pos $10^{\circ}$ tooth at $4000 \mathrm{rpm}$ ) to cut the surface in all three anatomical planes. To get a planed surface (radial and tangential), we used a woodworking surface planer (with 4 blades, head diameter $120 \mathrm{~mm}$ and $5000 \mathrm{rpm}$ ). Sanding was done on woodworking belt-sanding machine with sand paper grit sequence $80 / 120 / 240$ in all three wood sections (cross, radial, tangential). All final samples were prepared as $1 \mathrm{~cm}^{3}$ cubes. Split and planed wood was observed on longitudinal sections only (as it was impossible to split wood across the axial direction), and sawn and sanded specimens on all three xylotomical planes.

A more meticulous approach was developed to perform detailed wood anatomical observations by cutting wood with microtome blades. We prepared small strictly oriented wood cubes $\left(1 \mathrm{~cm}^{3}\right)$ processed with several pre-treatments before obtaining the final surface for observations.

Samples had been either dried, soaked in distilled water and frozen, or simply moistened for some seconds before cutting. One series of samples was also embedded in paraffin according to the standard procedure used for anatomical examinations of micro-cores (Prislan et al., 2009; Rossi et al., 2006; Balzano et al., 2018, Balzano et al., 2019).

Obtained samples were cut with a sliding microtome (Leica LM2010R) using either classic microtome blade (Leica) or replaceable Low Profile Microtome Blades (Leica DB80 LX) using a special blade holder - Low Profile Blade Rail Twin set (Leica). We cut $20 \mu \mathrm{m}$ thick wood slices. When cutting with a microtome, we always trimmed wood surface for optimal 

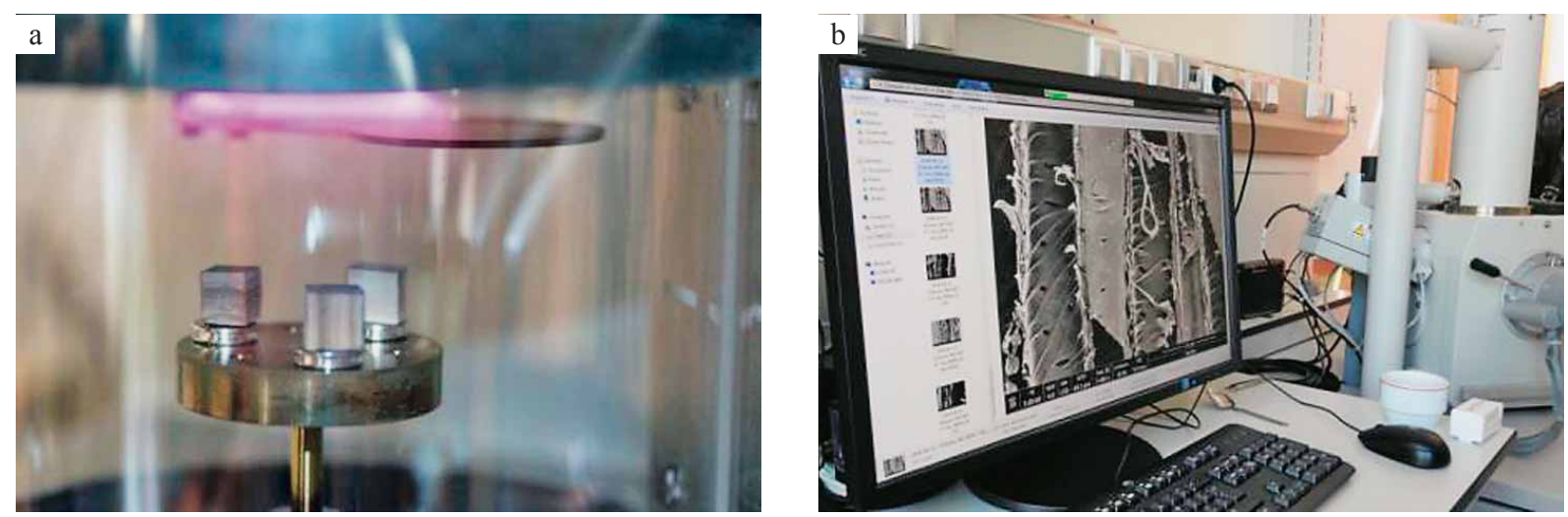

Figure 1 a) Oriented wood samples during gold coating in a Q150R ES Coating System; b) Scanning Electron Microscope (SEM) FEI QUANTA 250

Slika 1. a) Položaj uzoraka drva tijekom nanošenja pozlate parom u Q150R ES Coating System; b) pretražni elektronski mikroskop (SEM) FEI QUANTA 250

orientation and position and, thereafter, moved the blade to a new position to make one clear final cut with a new sharp cutting edge.

Finally, the cut samples were dried at laboratory conditions $\left(T=22{ }^{\circ} \mathrm{C}\right.$ and $\left.\mathrm{RH}=65 \%\right)$ before SEM analyses. Samples that were soaked in water and frozen were first put at $T=4{ }^{\circ} \mathrm{C}$ and $\mathrm{RH}=65 \%$ for $24 \mathrm{~h}$ and afterwards dried in laboratory conditions to prevent fast drying and possible drying cracks. One series of frozen samples was freeze-dried (Telstar Lyo Quest).

The dried samples were mounted on stubs with a conductive carbon adhesive tab and part of them were coated with $\mathrm{Au} / \mathrm{Pd}$ sputter-coater (Q150R ES Coating System; Quorum technologies, Laughton, UK) (Figure 1a) for 60 seconds with a constant current of $20 \mathrm{~mA}$, while others remained uncoated. The thickness of gold layer deposited on the sample surface depended on the time of exposure and the sputtering current set in the system. If the layer was too thick, the surface details could be obscured. If the layer was too thin, the surface could undergo excessive charging resulting in a weak signal and low-quality images. In this way, we also checked the SEM analyses quality with and without coating.

The SEM micrographs were then taken in low voltage (5 to $10 \mathrm{kV}$ ) and low vacuum $(50 \mathrm{~Pa})$ conditions with a large field (LFD) detector in a FEI Quanta 250 SEM microscope (FEI Company, Hillsboro, Oregon, USA) (Figure 1b) at working distances between 7 and $11 \mathrm{~mm}$.

The appropriate voltage depended on samples structure. High voltage beam generally resulted in a higher signal and better resolution, with the possibility of penetrating the samples surface, thus producing the signal from below the specimen's surface resulting in an unfairly information-rich image. Charging effect was also more pronounced after a few minutes at 10 $\mathrm{kV}$, especially on non-coated specimens. Voltage of 5 $\mathrm{kV}$ was high enough to provide a high resolution image and at the same time avoid damaging the wood surface.

After SEM analyses of surfaces on all three sections (cross, radial and tangential) on beech wood, we selected technical optimal methodology for wood surface preparation. Optimal results were obtained by cutting a pre-moistened wood surface with a sliding mi- crotome using a replaceable low-profile blade. According to this developed methodology, we finally prepared three strictly oriented cubes $\left(1 \mathrm{~cm}^{3}\right)$ for each of the selected four invasive alien wood species to be analyzed for detailed anatomical structure by SEM.

\section{RESULTS AND DISCUSSION \\ 3. REZULTATI I RASPRAVA}

\subsection{Surface after processing}

3.1. Površina nakon pripreme

The first part of the results presents surface appearance obtained by different woodworking processes (Figure 2). Different woodworking operations on radial and tangential plane open the wood structure so that we can recognize some wood cells (Figure 2). Figure 2a shows the surface after sanding with final sand paper grit 240. We can recognize rays, distribution of fiber with bordered pits and a vessel. Planed surface seemed to be slightly better as we can also clearly recognize individual vessel elements with intervessel pits, as well as pits between vessel and ray parenchyma (Figure $2 b$ ).

We can see that, in case of sanding the cross section, all cell lumina are filled and closed with the sanded cell wall material (Figure 2c). In this case, the penetration of impregnation or coatings cannot be as effective as cutting with circular saw (Figure 2d), where at least some of vessel lumina are still partly opened. These results are important if we aim to understand surface wood permeability before impregnation or coating. None of the described wood working operations gives a surface where it would be possible to observe wood anatomical details.

Splitting of wood in radial and tangential plane (Figure 2e and 2f) display all characteristic features of beech wood. When splitting wood, we do not cut, brush, remove or relocate cell wall matrix - splitting simply divides cells along the weakest adhesion layer and in most cases this is middle lamella. After splitting on radial section, we can clearly recognize vessel elements with opposite intervessel pits, pits between vessel and ray parenchyma. Simple perforation plates can be seen between vessel elements (Figure 2e). Among vessels, we can observe fiber with bordered or modi- 

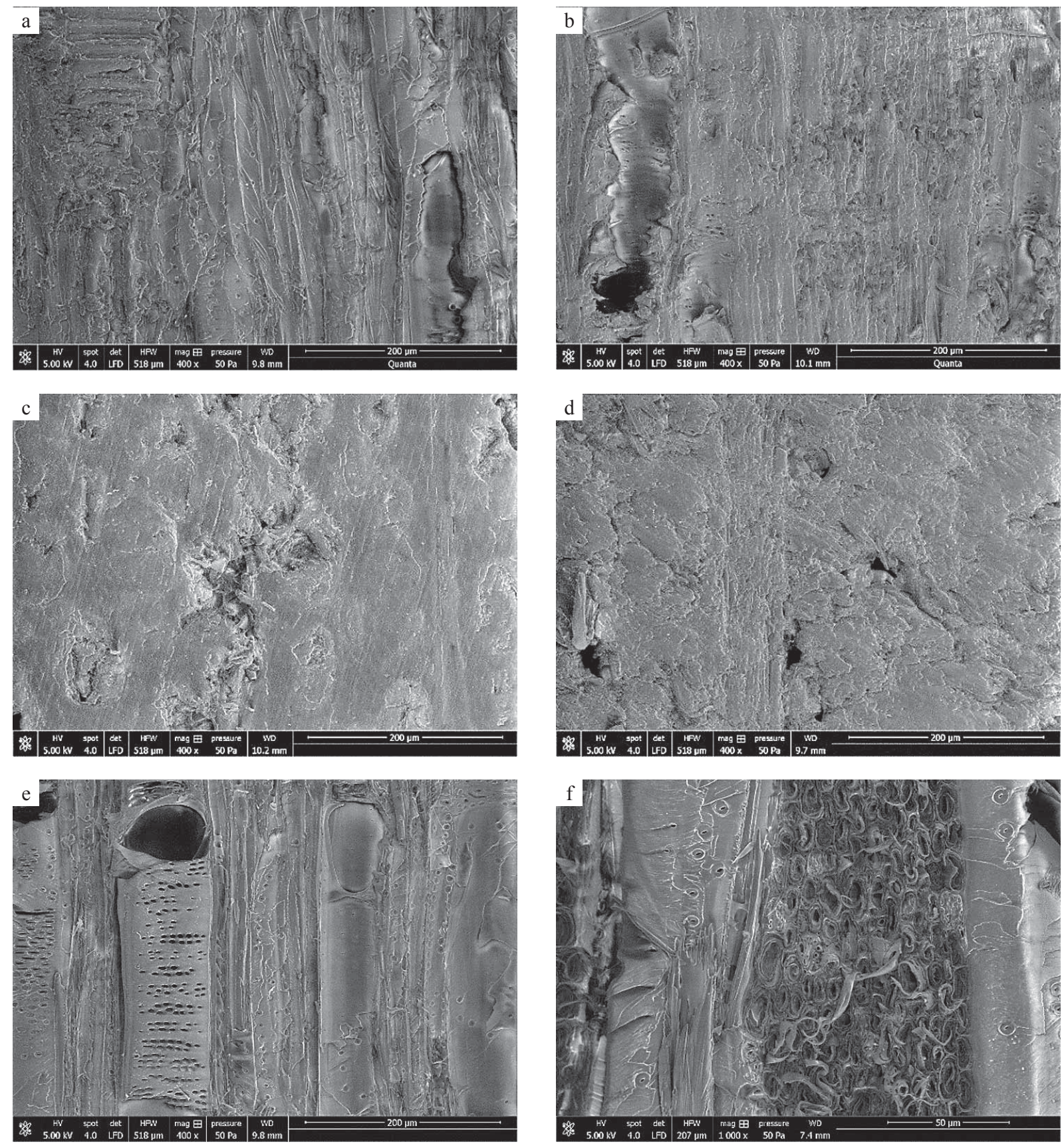

Figure 2 Beech (Fagus sylvatica), SEM: a) radial surface after sanding, b) radial surface after planing, c) cross surface after sanding, d) cross surface after circular cut, e) radial surface after splitting and f) tangential section after splitting

Slika 2. Bukovina (Fagus sylvatica), SEM: a) radijalni presjek nakon brušenja, b) radijalni presjek nakon blanjanja, c) poprečni presjek nakon brušenja, d) poprečni presjek nakon blanjanja, e) radijalni presjek nakon cijepanja, f) tangentni presjek nakon cijepanja

fied bordered pits. The same features could be recognized on split tangential section (Figure 2f), where we can also see a wide ray. Ray parenchyma cells were split by being pulled in their longitudinal direction and parts of cell walls can be seen as pulled out spiral structures - remains of cell wall matrix before crushing. We can also observe simple pits between parenchyma cells. Results showed that observation of wood structure in radial and tangential section is possible if the wood is split without any pre-treatment.

\subsection{Cross section preparation}

Due to cell orientation, the cross section surface preparation proved to be the most difficult and could only be prepared by cutting with microtome. Figure 3 presents the results of beech wood cross section cut with two different blades and subjected to several different wood pre-treatments.

In the first row, we present cutting of dried and non-pre-treated samples by solid microtome blade and replaceable low profile blade (Figure $3 b$ ). Solid blade cutting opened clear cell structure but detailed analysis revealed that cell walls of vessel elements as well as axial parenchyma and ground tissue were scraped and cell matrix was pushed partly into cell lumina (Figure 3a). Cutting with replaceable blade was better, cell walls were not scraped and cell lumina were clearer. However, since low profile replaceable blade is very thin and slim, it vibrates when cutting dry wood thus leaving marks on 
the surface of the specimen (Figure 3b). To avoid blade vibration during cutting (also called chattering), we prepared sample pre-treated in paraffin by the standard procedure for micro-core samples (Balzano et al., 2018). After the treatment, paraffin was washed from the surface by bio-clear (D-limonene) before cutting. We were able to make high quality cut, but in spite of the leaching and purification, residues of paraffin were observed in the cell lumina during the analysis, as well as on some parts of the cell wall (Figure 3c). From the samples that were immersed and soaked in water and then frozen, we obtained one of the best and clearest cross surfaces (Fig-
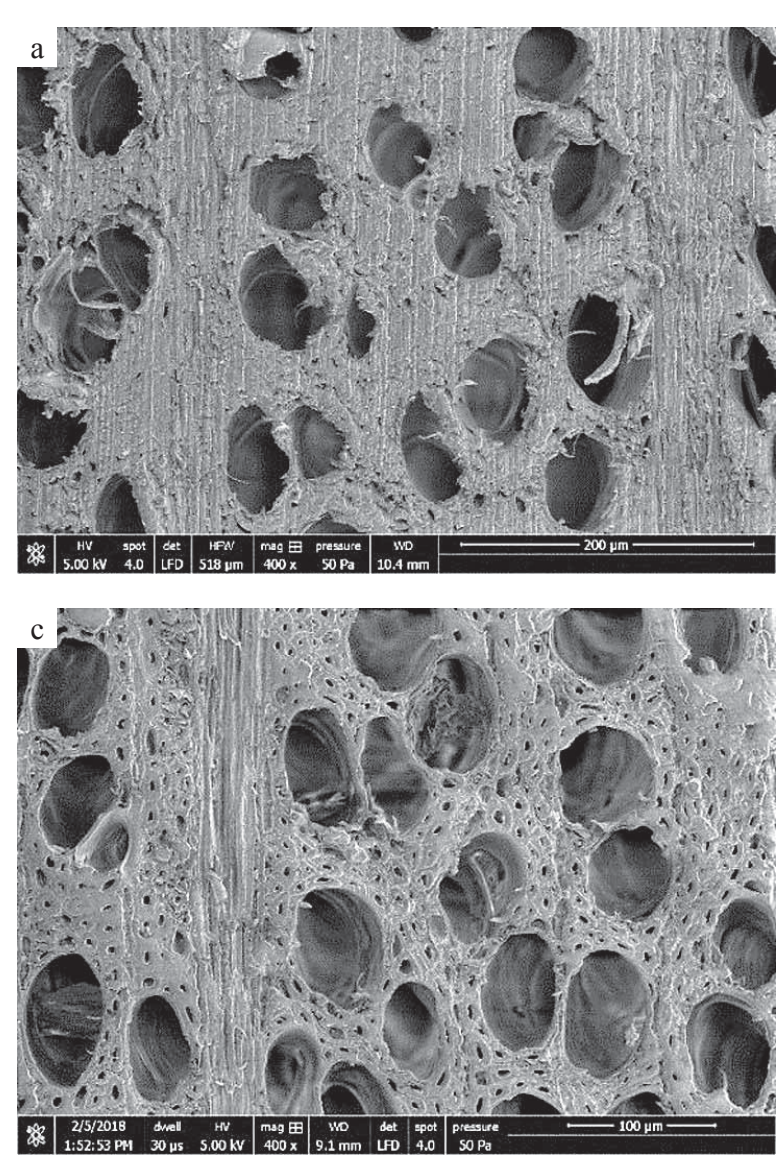

ure 3d). We can see that all cell walls were cut clear and that cell lumina were intact. Very similar results were obtained after cutting of pre-moistened surface (Figure 3e). Since soaking, freezing and drying after cutting proved to be time consuming and technically demanding, it was concluded that optimal surface preparation was wetting the surface with distilled water immediately before cutting (Figure 3e).

After defining optimal pre-treatment and cutting by microtome low profile replicable blade, we also tested SEM analyses of non-coated and gold coated (with different parameters) wood surface (Figure 4).
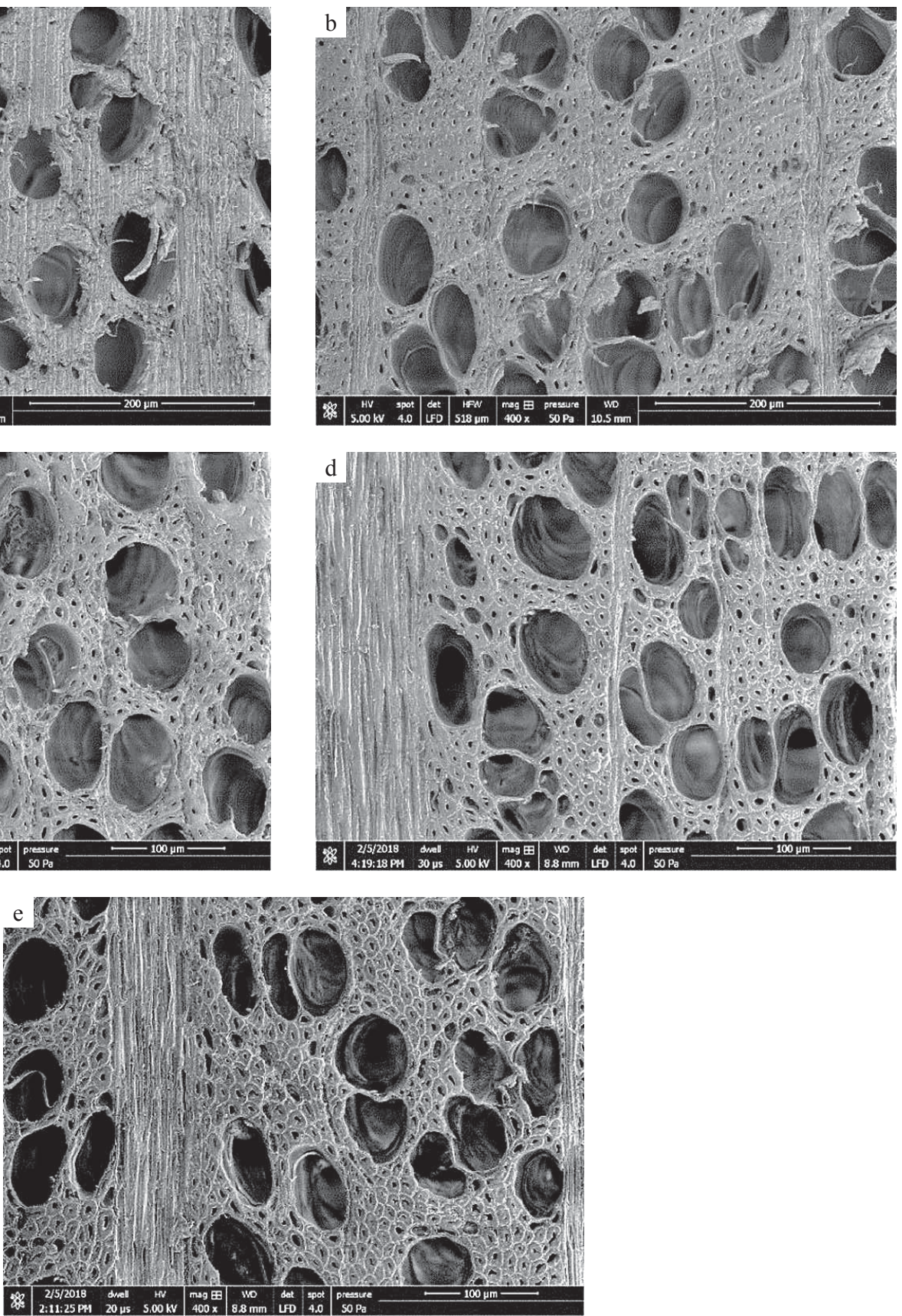

Figure 3 Beech (Fagus sylvatica), SEM, cross section cut on microtome: a) solid blade cut - no pre-treatment, b) replaceable blade cut - no pre-treatment, c) replaceable blade cut - wood pre-treated by paraffin, d) replaceable blade cut - wood pre-treatment by freezing and e) replaceable blade cut with a pre-moistened wood surface

Slika 3. Bukovina (Fagus sylvatica), SEM, poprečni presjek rezan na mikrotomu: a) čvrstim nožem - bez predtretmana, b) nožem s izmjenjivim oštricama - bez predtretmana, c) nožem s izmjenjivim oštricama - uz predtretiranje drva parafinom, d) nožem s izmjenjivim oštricama - uz predtretiranje drva zamrzavanjem, e) nožem s izmjenjivim oštricama - površina drva navlažena 

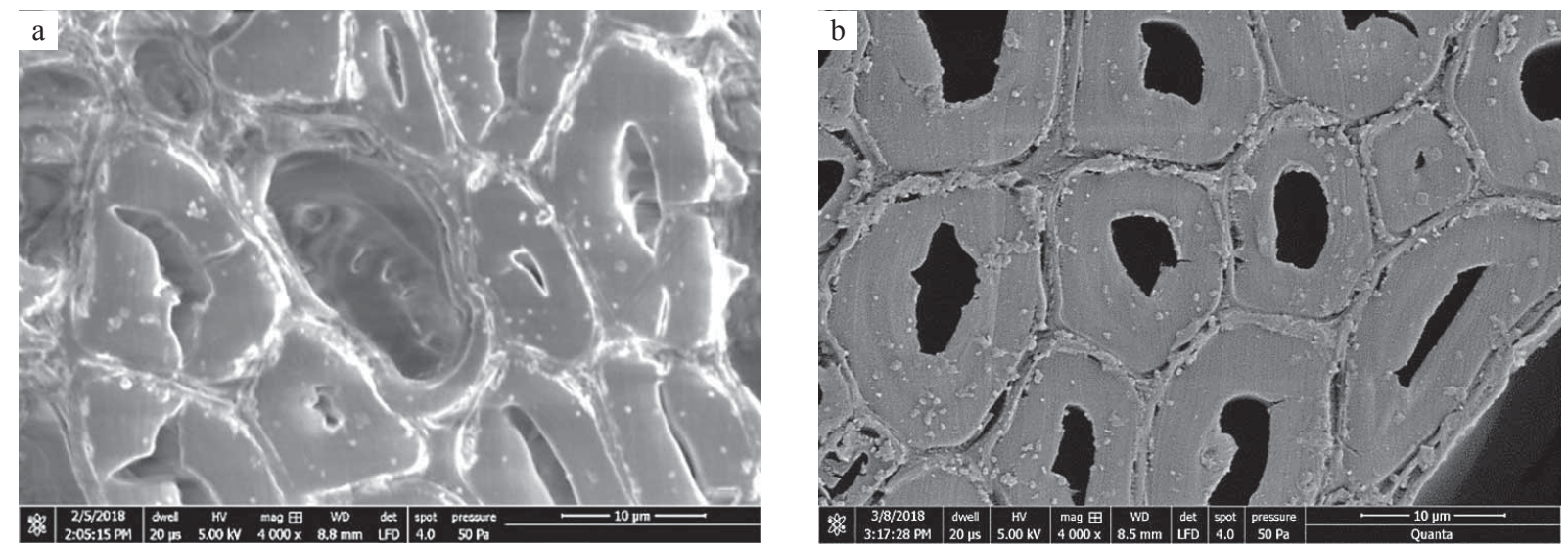

Figure 4 Beech (Fagus sylvatica), SEM, cross section: a) non- coated wood and b) gold coated wood surface

Slika 4. Bukovina (Fagus sylvatica), SEM, poprečni presjek: a) nepremazano drvo, b) pozlata parom nanesena na površinu drva

Low conductivity specimens have a limited ability of discharging electrons from the sample surface to the metal stub (and finally on the grounded parts of the microscope), resulting in the so-called charging effect (the over-lit edges of cells in Figure 4a), displayed at $4.000 \times$ magnification. The phenomenon could be a result of poor contact between the specimen and the mount, inadequate metal coating or inadequate bulk conductivity. The coated surface gave much better results for SEM analyses, especially at higher magnifications (Figure 4b).
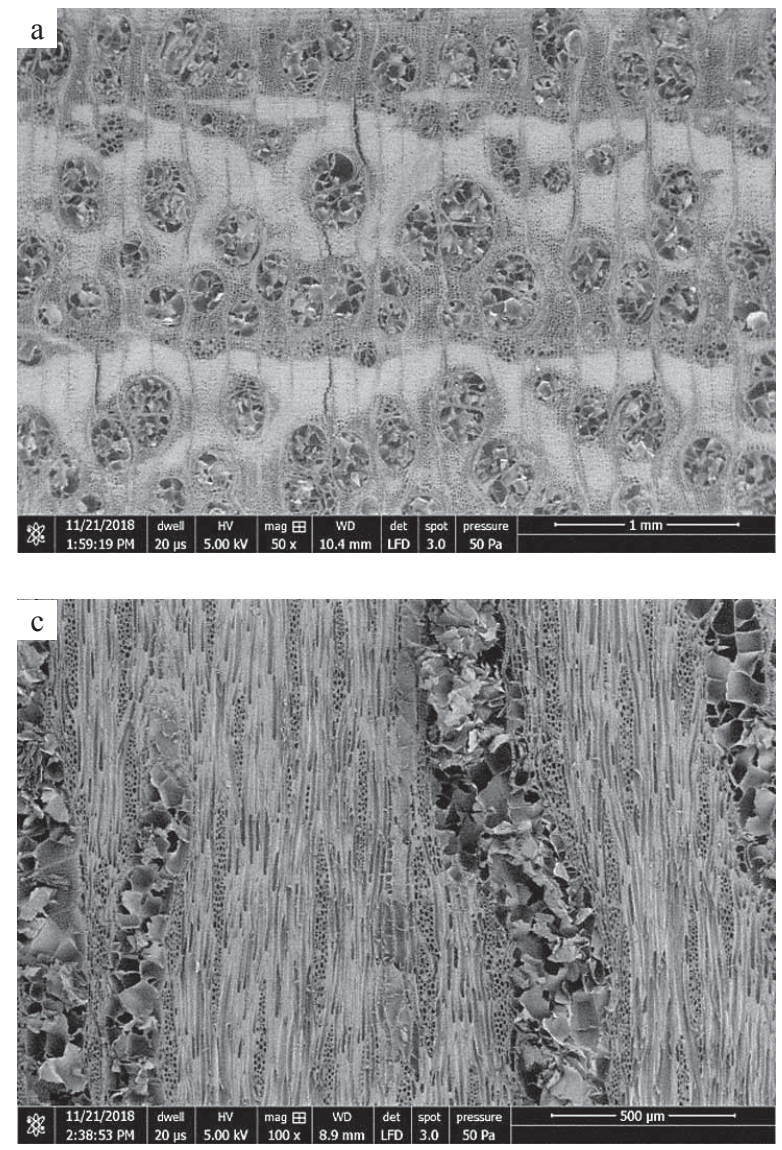

\subsection{Wood anatomical investigation of invasive species by SEM}

3.3. Istraživanje anatomije invazivnih vrsta drva uz pomoć SEM-a

The wood of invasive species was used as the main research material. In Slovenia several invasive plant species are very widespread and locally forming large stands. Since uncontrolled spreading became a serious problem, there have been many projects addressing this issue and one of them is APPLAUSE. Activities of APPLAUSE project makes it easier for the
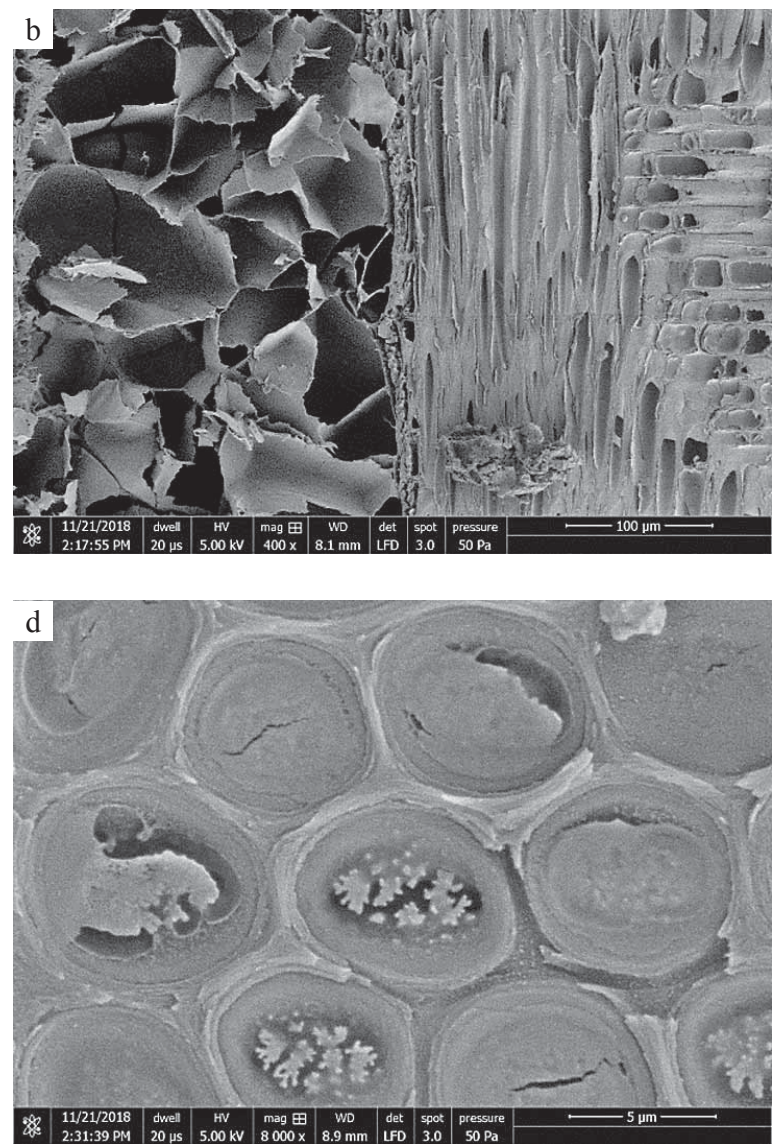

Figure 5 Black locust (Robinia pseudoacacia), heartwood, SEM: a) cross section, b) radial section, c, d) tangential section at various magnifications

Slika 5. Drvo bagrema (Robinia pseudoacacia), srž, SEM: a) poprečni presjek, b) radijalni presjek, c) i d) tangentni presjek pri različitim povećanjima 
citizens to recognize invasive wood plant species and then remove and process them into useful products. Seventeen invasive wood species were identified and their properties were analyzed to find potential innovative solutions for their use. Wood anatomy research knowledge is necessary when characterizing wood properties.

One of the fastest spreading non-native invasive tree species is black locust (Robinia pseudoacacia), which has distinct growth rings with a ring-porous structure (Figure 5a). Earlywood as well as latewood vessels are abundantly filled with tyloses (Figure 5a-c). On SEM images, we can observe how dense and complex the structure is built from tyloses along the vessel elements. Chemical components present in the cell walls of black locust wood are crucial for its durability; tyloses present a strong barrier that obstructs the spread of fungal hyphae through the vessels. High resolution SEM images at $8000 \times$ magnification also show vestured pits in vessel elements (Figure 5d), not often observed in Robinia pseudoacacia.

The staghorn sumac (Rhus typhina) has an interesting wood structure. On the cross section (Figure 6a), we can see the semi-to ring-porous vessel distribution. Growth rings are distinct. Vessels in latewood are grouped in radial multiples and also in clusters. Body ray cells are procumbent with one or two rows of upright square marginal cells (Figure 5b). On the tangential section, we can clearly recognize 1 to 3 seriate rays (Figure 6c) and helical thickenings in vessel elements. Figure $6 \mathrm{~d}$ shows detailed spatial distribution of helical thickenings and intervessel pits at the $3.000 \times$ magnification.

Desert false indigo (Amorpha fruticosa) cross section (Figure 7a) shows thin walled fiber from 10 to $20 \mu \mathrm{m}$ in diameter and ray parenchyma cells filled with starch grains indicating their storage function. Desert false indigo wood is semi- to ring-porous and Figure $7 \mathrm{~b}$ shows a detail on tangential section, where we can see that vessel elements on the transition from early- to latewood - vessels are up to $80 \mu \mathrm{m}$ long and up to 50 $\mu \mathrm{m}$ in diameter. Biseriate rays can be observed on tangential section (Figure 7c). Starch grains in axial parenchyma are 1 to $4 \mu \mathrm{m}$ in diameter and up to $5 \mu \mathrm{m}$ long (Figure $7 \mathrm{c}, \mathrm{d}$ ).

Red osier dogwood (Cornus sericea) has a diffuse-porous wood, ground tissue consisting of thin to thick walled fibers and diffuse axial parenchyma (Figure 8a). Tangential section shows vessels elements with alternate intervessel pits and long scalariform perforations with 20-40 bars (Figure 8b). Observation of vessel perforations at higher magnifications (up to $12.000 \times$ ) revealed the remnants in the scalariform perforation plate (Figure $8 \mathrm{~d}$ and $8 \mathrm{e}$ ). Similar structures were observed in Illicium tashiroi (Carlquist, 1992). The remnants in the perforation plate of red osier dogwood can be defined as extensive band-like remnants that form strands running in an axial direction.
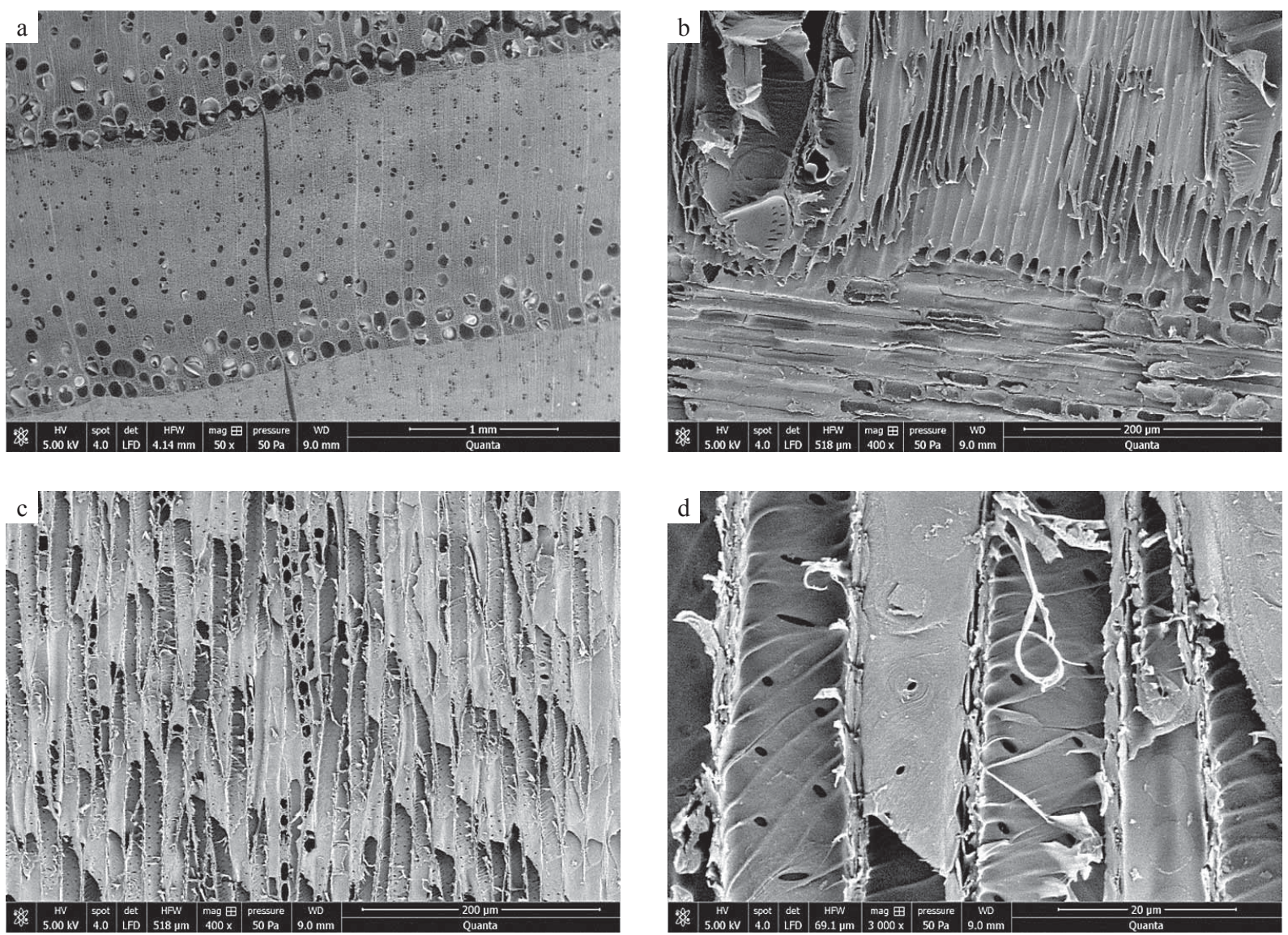

Figure 6 Saghorn sumac (Rhus typhina), SEM: a) cross section, b) radial section, c) tangential section and d) tangential section at larger magnification

Slika 6. Kiseli ruj (Rhus typhina), SEM: a) poprečni presjek, b) radijalni presjek, c) tangentni presjek, d) tangentni presjek pri većem povećanju 

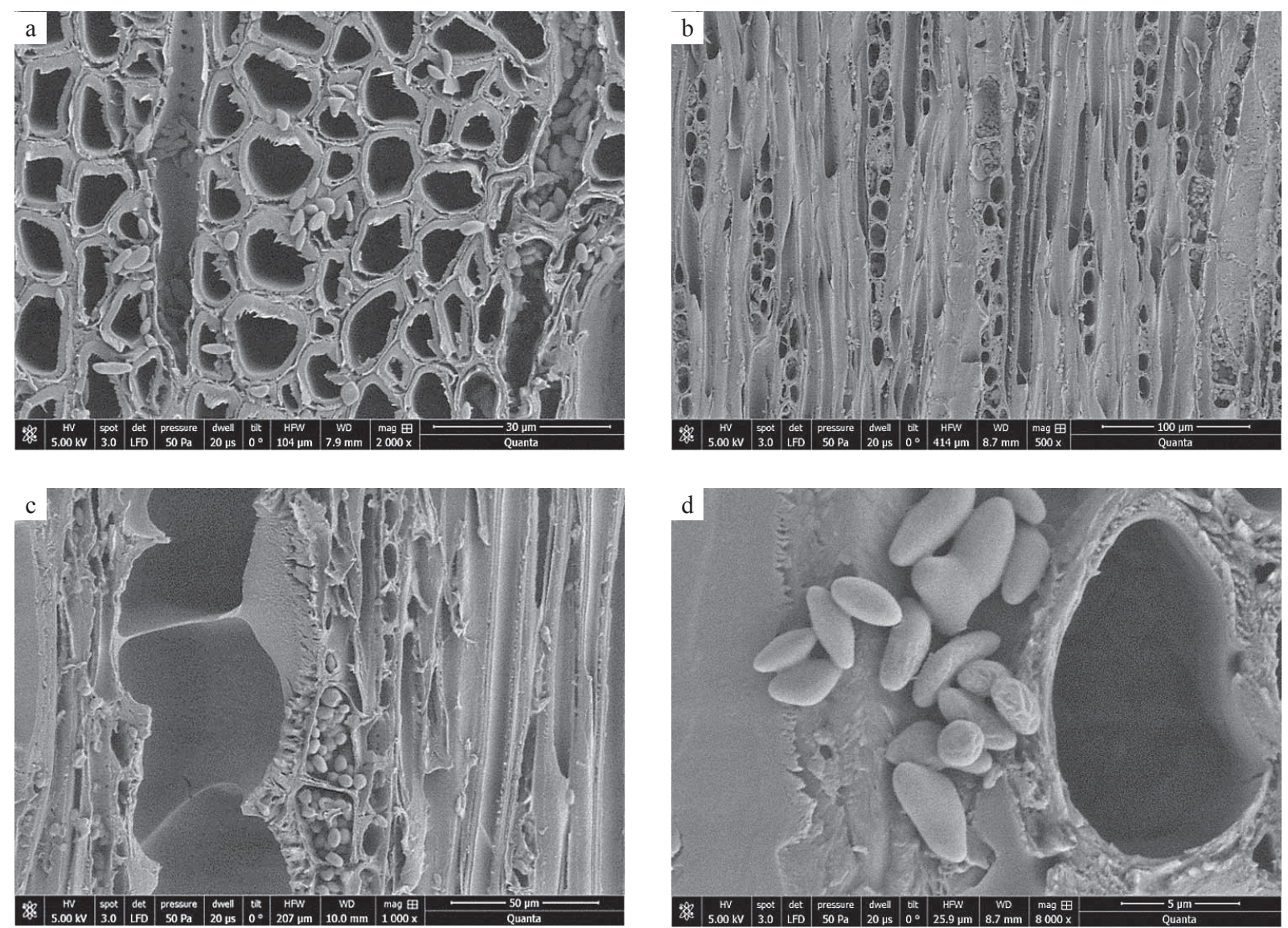

Figure 7 Desert false indigo (Amorpha fruticosa), SEM: a) cross section, b, c, d) tangential section at various magnifications Slika 7. Amorfa (Amorpha fruticosa), SEM: a) poprečni presjek, b), c) i d) tangentni presjek pri različitim povećanjima
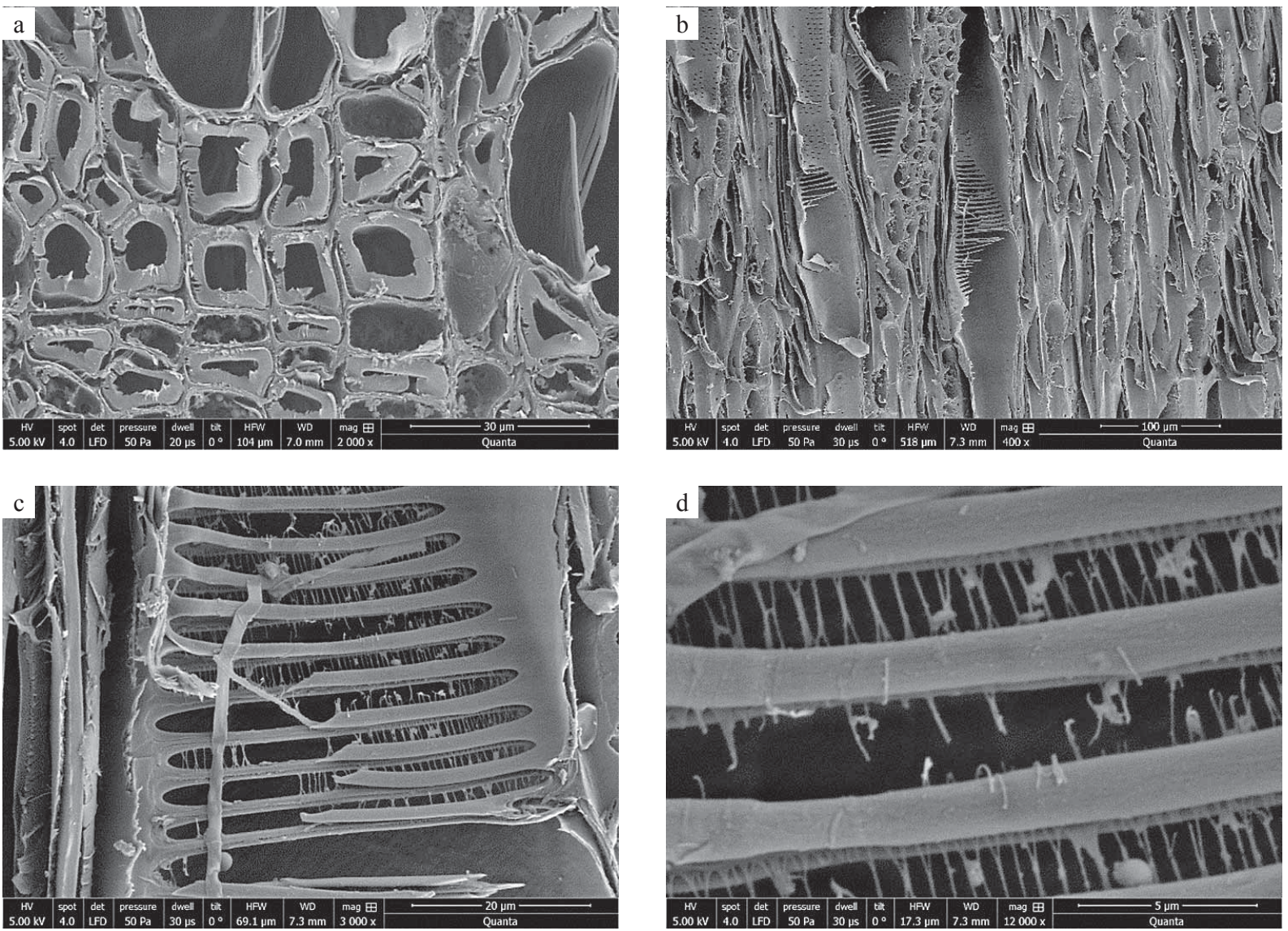

Figure 8 Red osier dogwood (Cornus sericea), SEM: a) cross section, b, c, d) tangential sections at various magnifications

Slika 8. Drijen (Cornus sericea), SEM: a) poprečni presjek, b), c) i d) tangentni presjek pri različitim povećanjima 


\section{CONCLUSIONS}

\section{ZAKLJUČAK}

We optimized a method for the preparation of wooden specimens for SEM analysis. Since the method is fast and technically less demanding, it allows observation of a larger sample series on daily basis.

The best results were obtained by cutting a frozen surface using a sliding microtome with a low-profile replaceable blade followed by gold coating. However, the optimal results (considering everything from time consumption to price) were obtained by a pre-moistened surface cut on a sliding microtome with a lowprofile replaceable blade followed by gold coating. We were able to prepare samples of selected invasive alien wood species for detailed SEM analyses. The developed method enabled us to observe details that can be detected only at high magnifications. High resolution images at high magnifications (up to $12.000 \times$ ) prove that the proposed technique works for advanced wood anatomy investigations. We displayed complex structures of tyloses and vestured pits in vessels of Robinia pseudoacacia, spatial distribution of helical thickenings in Rhus typhina, starch grains in Amorpha fruti$\cos a$ and scalariform perforations with rarely observed band-like remnants in Cornus sericea.

The technique is now used on a daily basis for SEM analyses at the Department of Wood Science and Technology of Biotechnical Faculty in Ljubljana.

\section{Acknowledgements - Zahvala}

Research was done within the project APPLAUSE (UIA02-228) co-financed by the European Regional Development Fund through the Urban Innovative Actions Initiative (www.ljubljana.si/en/applause/). The work was additionally supported by the Program P4-0015, cofinanced by the Slovenian Research Agency. The authors thank Luka Krže, Jože Planinšič, and Janez Novak for their immense help with the sample preparation and with the results analysis.

\section{REFERENCES}

5. LITERATURA

1. Anfodillo, T.; Sigalotti, G. B.; Tomasi, M.; Semenzato, P.; Valentini, R., 1993: Applications of a thermal imaging technique in the study of the ascent of sap in woody species. Plant, Cell \& Environment, 16 (8): 997-1001. https://doi.org/10.1111/j.1365-3040.1993.tb00524.x.

2. Ashworth, E. N.; Stirm, V. E.; Volenec, J. J., 1993: Seasonal variations in soluble sugars and starch within woody stems of Cornus sericea L. Tree Physiology, 13 (4): 379-388. https://doi.org/10.1093/treephys/13.4.379.

3. Atack, D.; Smith, K. C. A., 1956: The scanning electron microscope. A new tool in fiber technology. Pulp and paper magazine of Canada (Convention issue), 57: 245-251.

4. Balzano, A.; Čufar, K.; Battipaglia, G.; Merela, M.; Prislan, P.; Aronne, G.; De Micco, V., 2018: Xylogenesis reveals the genesis and ecological signal of IADFs in Pinus pinea L. and Arbutus unedo L. Annals of botany, 121 (6): 1231-1242. https://doi.org/10.1093/aob/mcy008.

5. Balzano, A.; De Micco, V.; Merela, M.; Čufar, K., 2019: Tree-rings in Mediterranean pines-can we describe them to calendar years? Les, 68 (1): 5-14.
6. Baradit, E.; Aedo, R.; Correa, J., 2005: Knots detection in wood using microwaves. Wood Science and Technology, 40 (2): 118-123. https://doi.org/10.1007/s00226-005-0027-8.

7. Boero, F.; Fedeli, A.; Lanini, M.; Maffongelli, M.; Monleone, R.; Pastorino, M.; Randazzo, A.; Salvadè, A.; Sansalone, A., 2018: Microwave Tomography for the Inspection of Wood Materials: Imaging System and Experimental Results. IEEE Transactions on Microwave Theory and Techniques, 66 (7): 3497-3510. https://doi.org/10.1109/TMTT.2018.2804905.

8. Bucur, V., 2003: Non-destructive Characterization and Imaging of Wood. Heidelberg, Springer, $354 \mathrm{p}$.

9. Busse, G., 2001: Lock in thermography. V: Nondestructive Testing Handbook, vol. 3. Infreared and Thermal Testing. Maldague, X. (ur.). Columbus, American Society for Nondestructive Testing: 318-327.

10. Carlquist, S., 1982: The use of ethylenediamine in softening hard plant structures for paraffin sectioning. Stain technology, 57 (5): 311-317.

11. Carlquist, S., 1992: Pit Membrane Remnants in Perforation Plates of Primitive Dicotyledons and Their Significance. American Journal of Botany, 79: 660-672.

12. Chen, Z.; Gabbitas, B.; Hunt, D., 2005: A thermal imaging technique for studying crack development in wood under torsional loading. Journal of Materials Science, 40 (8): 1929-1935. https://doi.org/10.1007/s10853-005-1213-7.

13. Collett, B. M., 2007: Scanning electron microscopy: A review and report of research in wood science. Wood and Fiber Science, 2 (2): 113-133.

14. Craig, R. B., 2013: Visualizing wood anatomy in three dimensions with high-resolution X-ray micro-tomography $(\mu \mathrm{CT})$ - a review - IAWA, 34 (4): 408-424. https://doi.org/10.1163/22941932-00000033.

15. Exley, R. R.; Meylan, B. A.; Butterfield, B. G., 1977: A technique for obtaining clean cut surfaces on wood samples prepared for the scanning electron microscope. Journal of Microscopy, 110 (1): 75-78.

16. Findlay, G. W. D.; Levy, J. F., 1969: Scanning electron microscopy as an aid to the study of wood anatomy and decay. Journal of the Institute of Wood Science, 5 (5): 57-63.

17. Goldstein, J. I.; Newbury, D. E.; Michael, J. R.; Ritchie, N. W.; Scott, J. H. J.; Joy, D. C., 2017: Scanning electron microscopy and X-ray microanalysis. Springer, $550 \mathrm{p}$.

18. Hanks, S.; Fairbrothers, D. E., 1970: Effects of preparation technique on pollen prepared for SEM observations. Taxon, 19 (6): 879-886.

19. Hansson, L.; Lundgren, N.; Antti, A. L.; Hagman, O., 2005: Micro wave penetration in wood using imaging sensor. Measurement, 38 (1): 15-20. https://doi.org/10.1016/j.measurement.2005.03.007.

20. Jansen, S.; Kitin, P.; De Pauw, H.; Idris, M.; Beeckman, H.; Smets, E., 1998: Preparation of wood specimens for transmitted light microscopy and scanning electron microscopy. Belgian Journal of Botany, 131 (1): 41-49.

21. Jansen, S.; Piesschaert, F.; Smets, E., 2000: Wood anatomy of Elaeagnaceae, with comments on vestured pits, helical thickenings, and systematic relationships. American Journal of Botany, 87 (1): 20-28.

22. Jansen, S.; Pletsers, A.; Sano, Y., 2008: The effect of preparation techniques on SEM-imaging of pit membranes. IAWA Journal, 29 (2): 161-178.

23. Kossah, R.; Zhang, H.; Chen W., 2011: Antimicrobial and antioxidant activities of Chinese sumac (Rhus typhina L.) fruit extract. Food Control, 22 (1): 128-132. https://doi.org/10.1016/j.foodcont.2010.06.002. 
24. Mayo, S. C.; Chen, F.; Evans, R., 2010: Micron-scale 3D imaging of wood and plant microstructure using highresolution X-ray phase-contrast micro tomography. Journal of Structural Biology, 171: 182-188.

https://doi.org/10.1016/j.jsb.2010.04.001.

25. Merela, M.; Oven, P.; Serša, I.; Mikac, U.; 2009a: A single point NMR method for an instantaneous determination of the moisture content of wood. Holzforschung, 63 (3): 348-351. https://doi.org/10.1515/HF.2009.050.

26. Merela, M.; Pelicon P.; Vavpetič, P.; Regvar, M.; VogelMikuš, K.; Serša, I.; Poličnik, H.; Pokorny, B.; Levanič, T.; Oven, P., 2009b: Application of micro-PIXE, MRI and light microscopy for research in wood science and dendroecology. Nuclear Instruments and Methods in Physics Research Section B: Beam Interactions with Materials and Atoms, 267 (12): 2157-2162. https://doi.org/10.1016/j.nimb.2009.03.062.

27. Merela, M.; Sepe, A.; Oven, P.; Serša, I., 2005: Threedimensional in vivo magnetic resonance microscopy of beech (Fagus sylvatica L.) wood. Magma, 18 (4): 171174.

28. Meylan, B. A.; Butterfield, B. G., 1978a: Three-dimensional structure of wood. A scanning electron microscope study. Syracuse University Press.

29. Meylan, B. A.; Butterfield, B. G., 1978b: Helical orientation of the microfibrils in tracheids, fiber and vessels. Wood Science and Technology, 12 (3): 219-222.

30. Nagai, S.; Ohtani, J.; Fukazawa, K.; Wu, J., 1994: SEM observations on perforated ray cells. IAWA Journal, 15 (3): 293-300.

31. Niemz, P.; Kucera, L. J.; Flisch, A.; Blaser, E., 1997: Anwendung der Computer tomographie an Holz (Computerized tomography of wood). Holz als Roh- und Werkstoff, 55 (2): 279-280.

32. Novak, J., 2018: Priprava površin lesa za slikanje z vrstičnim elektronskim mikroskopom (Surface preparation of wooden samples for scanning electron microscopy), M. Sc. Thesis, Ljubljana.

33. Orwa, C.; Mutua, A.; Kindt, R.; Jamnadass R.; Anthony, S., 2009: Agroforestree Database: a tree reference and selection guide version 4.0. http://www.worldagroforestry.org/output/agroforestree-database (Accessed Jun 10, 2018).

34. Oven, P.; Merela, M.; Mikac, U.; Serša, I., 2011: Application of 3D magnetic resonance microscopy to the anatomy of woody tissues. IAWA Journal, 32 (4): 401-414.

35. Oven, P.; Merela, M.; Mikac, U.; Serša, I., 2008: 3D magnetic resonance microscopy of a wounded beech branch. Holzforschung, 62 (3): 322-328.

36. Pastorino, M.; Salvade, A.; Monleone, R.; Bartesaghi, T.; Bozza, G.; Randazzo, A., 2007: Detection of defects in woods labs by using a microwave imaging technique. In: 2007 IEEE Instrumentation \& Measurement Technology Conference IMTC 2007: pp. 1-6.

https://doi.org/10.1109/IMTC.2007.379332.
37. Prislan, P.; Merela, M.; Zupančič, M.; Krže, L.; Čufar, K., 2009: Use of selected light microscopy techniques to investigate wood and bark. Les, 61 (5): 222-229.

38. Resch, A.; Blaschke, R., 1968: Ueber die Anwendung des Raster-Elektronen mikroskopes in der Holzanatomie. Planta (Berl.), 78 (1): 85-88.

39. Rossi, S.; Anfodillo, T.; Menardi, R., 2006: Trephor: A new tool for sampling microcores from tree stems, IAWA Journal, 27 (1): 89-97.

https://doi.org/10.1163/22941932-90000139.

40. Salvade, A.; Pastorino, M.; Monleone, R.; Randazzo, A.; Bartesaghi, T.; Bozza, G.; Poretti, S., 2008: Microwave imaging of foreign bodies inside wood trunks. In: 2008 IEEE International Workshop on Imaging Systems and Techniques, pp. 88-93. doi:10.1109/IST.2008.4659947.

41. Sanderson, J. B., 1994: Biological Microtechnique, Microscopy Handbook No. 28, Royal Microscopical Society Handbook Series. Bios Scientific Publishers, pp. 240.

42. Thomas, R. J., 2007: The ultrastructure of southern pine bordered pit membranes as revealed by specialized drying techniques. Wood and Fiber Science, 1 (2): 110-123.

43. Thomas, R. J.; Nicholas, D. D., 1966: Pit membrane structure in loblolly pine as influenced by solvent exchange drying. Forest Products Journal, 16 (3): 53-56.

44. Wagner, F. G.; Taylor, F. W.; Ladd, D. S.; McMillin, C. W.; Roder, F. L., 1989: Ultrafast CT scanning of an oak $\log$ for internal defects. Forest Products Journal, 39 (11/12): 62-64.

45. Wang, E. T.; Van Berkum, X.; Sui, H.; Beyene, D.; Chen, W. X.; Martinez-Romero, E., 1999: Diversity of rhizobia associated with Amorpha fruticosa isolated from Chinese soils and description of Mesorhizobium amorphae sp. nov. International Journal of Systematic Bacteriology, 49 (1): 51-65. https://doi.org/10.1099/00207713-49-1-51.

46. Zhou, W., Apkarian, R., Wang, Z. L. \& Joy, D., 2006: Fundamentals of scanning electron microscopy (SEM). In Scanning microscopy for nanotechnology. Springer, New York, pp. 1-40.

47. Žlahtič Zupanc, M.; Mikac, U.; Serša, I.; Merela, M.; Humar, M., 2017: Distribution and penetration of tung oil in wood studied by magnetic resonance microscopy. Industrial Crops and Products, 96: 149-157. https://doi.org/10.1016/j.indcrop.2016.11.049.

\section{Corresponding address:}

\section{Assoc. Prof. MAKS MERELA, PhD}

University of Ljubljana

Biotechnical Faculty

Department of Wood Science and Technology

Jamnikarjeva 101, 1000 Ljubljana, SLOVENIA

e-mail: maks.merela@bf.uni-lj.si 